\title{
The Effect of Oral Summary of Short Stories on Iranian Intermediate EFL Learners' Vocabulary Learning: With a Focus on Gender
}

\author{
Amir Reza Nemat Tabrizi ${ }^{1} \&$ Setareh Abbasi ${ }^{1}$ \\ ${ }^{1}$ Department of English Language, Payame Nour University, Iran \\ Correspondence: Amir Reza Nemat Tabrizi, Department of English Language, Payame Nour University, Iran. \\ E-mail: arnemati@pnu.ac.ir
}

Received: July 2, 2016 Accepted: October 30, 2016 Online Published: November 23, 2016

doi:10.5539/ijel.v6n6p129 URL: http://dx.doi.org/10.5539/ijel.v6n6p129

\begin{abstract}
This study investigated the effect of producing oral summary of short stories by language learners on vocabulary learning of EFL learners at intermediate level and the possible different effect of this classroom activity on male and female participants. In order to pursue the purpose of the study, one hundred twenty Iranian EFL learners were given Nelson proficiency test as the proficiency test and pretest. Seventy five learners were chosen as the participants for the study who formed one control group and two experimental groups. After twenty sessions of treatment, the participants were given a piloted version of a researcher-made test based on the vocabulary used in the short stories. The findings of the study proved that oral production of short stories can have a positive effect on vocabulary learning among intermediate learners, but the effect of this mode of teaching was not different on male or female language learners. The findings of the study could be used by language teachers who aim at conducting learner-centered language classes and material producers who aim at increasing the outcome of language courses by opting suitable course content.
\end{abstract}

Keywords: oral summary, short story, vocabulary

\section{Introduction}

\subsection{Introduce the Problem}

Vocabulary learning as mentioned by Nunan (1999) occurs in a meaningful context and not in isolation. On the other hand, based on swain's output hypothesis (1985) what is supposed to be learnt can better be learnt if the learners are given the opportunity to produce it as output. In fact, swain's belief is that a more suitable approach for learning languages in EFL/ESL settings is output as compared to input. These issues perpetuate the importance of oral production of short stories as not only is the emphasis in this approach on the output produced by the learners, but also its focus is on stories as meaningful contexts.

Although many prior studies such as the ones carried out by Isbell et al. (2004), Al-Dersi (2013) and Tavanpur \& Gorjian (2014) delved into the effect of production of stories on learning the second language; (a) their emphasis was on production of stories on skills such as reading and not vocabulary and (b) they basically focused on production of stories by the teachers and not the students. That is why, there is a need for a new study to investigate the possible effect of oral production of short stories on vocabulary learning among Iranian EFL learners.

Another problem in EFL/ESL classes in the context of Iran is that much of classroom time is dedicated to the teachers and language learners cannot make use of their time in the classroom to practice the language. In addition, many of the language learners, though familiar with a wide range of vocabulary, do not tend to use them when they talk, as they are either not sure about the pronunciation of the word or not sure about its accurate use in the sentence.

\subsection{Importance of the Problem}

The findings of the study can be significant from several different perspectives. First of all, if it proves that oral production of short stories has a positive effect on vocabulary learning among Iranian EFL learners at intermediate level, it can help introduce it as a possible classroom technique to teach vocabulary or as a homework for language students. On the other hand, the answer to the second research question which aims at finding out gender differences with regard to oral production of stories and vocabulary learning can further 
highlight possible psychological differences between language learners based on their gender. In addition, the findings of this study can better guide language teachers for shifting from input-oriented classroom activities to output-oriented ones.

The study can also help language teacher opt between two common classroom techniques with regard to using short stories in the classroom e.g. oral production of short stories by the teachers or the learners. Although the common practice by many language teachers is to produce the short stories by themselves, the findings of this study can prove whether or not this technique is the most effective or not.

\subsection{Relevant Scholarship}

As Nunan (1999) mentioned, learners should be given the maximum number of opportunities possible to practice the target language in meaningful context and situation. Here short story provides this context. As short stories commonly have a beginning, middle and an end, they may encourage students at all levels of language proficiency to continue reading them until the end to find out how the conflict is settled. Moreover, based on the Internet article "Using Literature in Teaching English as a Foreign/Second Language" (2004), "Literature is motivating. Literature holds high status in many cultures and countries. For this reason, students can feel a real sense of achievement at understanding a piece of highly respected literature. Also, literature is often more interesting than the texts found in course books". Having opportunities to speak the language may motivate the students to learn during reading activities of the new language elements that may be needed in future to facilitate speaking since students learn new words and forms. According to Chastain (1988) "having the opportunity to process language at the slower speed listening and speaking activities should take some of the pressure off and enable them to perform more comfortably and satisfactory". In this study by using short stories students can use the sentences in real communication and since they have pre-fabricated patterns and use the text to make summary, they can speak and so have motivation. According to Taylor (1983, p. 70), students acquire language by using it rather than learning it by studying it. Here by using oral summary of short stories students connect sentences and try to provide coherence, meaningful speech. In addition, the usefulness of this strategy is in its nature to be more directly related to individual learning task.

\subsection{Research Hypotheses}

The design used in the present research was considered as quasi experimental design. A typical experimental study usually uses control group and experimental groups to investigate research questions. As the control group exposed to traditional teaching and did not use of oral summary of short stories, the experimental groups received it. In the comparison group design, participants were randomly assigned to one of the groups, with treatment (the independent variable) differing between or among the groups.

The answer to the following research questions will be sought in this study:

Q1: Does oral summary of short stories have any effect on vocabulary learning of Iranian EFL learners at intermediate level?

Q2: if the answer to the research question 1 is "yes", which one of the male or female intermediate EFL learners benefits more?

Accordingly to the research questions, the following null hypotheses are formulated for the study:

H1: Oral summary of short stories has no effect on vocabulary learning of Iranian female EFL learners at intermediate level.

H2: Oral summary of short stories has more effect on vocabulary learning of Iranian male EFL learners than female learners at intermediate level.

\section{Method}

\subsection{Subsections of Method}

Through this section it has been tried to describe the steps taken for carrying out the current study. More specifically, the section will provide information about the participants, instruments, research design and procedure that were employed in this study.

\subsection{Participants}

The participants of the study were 75 intermediate Iranian EFL learners who were selected based on Nelson homogeneity test.

The table 1 below indicates how the intended participants were distributed in different groups. 
Table 1. Participants demographic data

\begin{tabular}{lllll}
\hline & $\mathrm{N}$ & Age & Gender & First language \\
\hline Control group & 23 & Adult & Male/female & Persian \\
Experimental group I & 24 & Adult & Female & Persian \\
Experimental group II & 24 & Adult & Male & Persian \\
\hline
\end{tabular}

\subsection{Sampling Procedure}

The participants for the study were chosen randomly among one hundred twenty $(\mathrm{N}=120)$ intermediate Iranian EFL learners who studied at Zaban Sara language institute in Miandoab, Iran. Nelson homogeneity test was administered to homogenize the students based on their general proficiency in English. Nelson homogeneity test is a fifty-item test designed by Fowler \& Creo (1976). After administering the homogeneity test and by considering $1 \mathrm{SD}$ above and below the mean score, seventy five $(\mathrm{N}=75)$ participants with their scores closest to the mean score, were chosen as the participants for the study.

\subsubsection{Sample Size}

The participants for the study were chosen randomly among one hundred twenty intermediate Iranian EFL learners.

\subsubsection{Measures and Covariates}

Seventy five participants were chosen out of one hundred twenty language learners for this study by administering Nelson Homogeneity test and by considering $1 \mathrm{SD}$ above and below the mean score and normal distribution of the participants' scores as a prerequisite for parametric studies. Next, the participants were given Nelson vocabulary test as the pretest. Based on the pretest scores, the participants were distributed into three different groups. The groups were labeled as control group, experimental group I (female) and experimental group II (male) with twenty five participants in each group The third phase of the study was the course of treatment which took twenty sessions in one month. In the control group the teacher produced oral summary of the short stories for the class, whereas in the experimental groups the participants were asked to produce oral summary of the short stories. After that, the participants took a researcher-made test as the posttest which contains 30 items from the vocabulary taught in the short stories.

\section{Instruments and Materials}

Nelson homogeneity test: Was given to the population in order to homogenize them based on their level of proficiency; namely, intermediate. Nelson test is a fifty item test designed by Fowler \& Croe (1976). The test consists of cloze tests, and multiple questions with the focus on grammar and choice of words.

Steps to Understanding: This is a widely used book to teach short stories to Iranian EFL learners in the context of Iran. The book is authored by Hill (1982).

Researcher-Made Posttest: as used to assess the participants' knowledge of vocabulary based on the vocabulary presented in the short stories.

\subsubsection{Research Design}

The study aimed at finding out if oral production of short stories had any effect on vocabulary learning among Iranian EFL learners with regard to their gender. Thus, the researcher made use of a true experimental design. True experimental studies are used in cases where there is a control group and randomization in choosing participants.

Three groups of participants formed for this study went through two different types of treatment. Although in all group short stories were taught, in the experimental groups the learners were asked to produce the short stories orally, whereas in the control group the learners were not asked to produce the stories orally. Instead, they were asked to read the short stories and answer the reading-comprehension questions at the end of the story.

\section{Data Analysis}

\subsection{Recruitment}

Nelson Proficiency test including 50 items was administered to 120 Iranian EFL learners as the proficiency test. The objective was twofold; first to prove that the subjects were correctly labeled as intermediate group and second to probe the reliability and validity of the instruments. Before discussing the results it should be mentioned that the data enjoyed normal distribution. As displayed in Table 2, the ratios of skewness and kurtosis over their respective standard errors were within the ranges of $+/-1.96$. 
Table 2. Normal distribution of the proficiency test

\begin{tabular}{ll}
\hline $\mathrm{N}$ & Valid 120 \\
\hline Skewness & .734 \\
Std. Error of Skewness & .221 \\
Kurtosis & .605 \\
Std. Error of Kurtosis & .438 \\
\hline
\end{tabular}

The reliability of the proficiency test scores was calculated using Crombach alpha formula. As displayed in table 3 the results of Crombach alpha $(\alpha=.96)$ prove that the scores were reliable.

Table 3. Reliability of the proficiency test scores

\begin{tabular}{ll}
\hline Cronbach's Alpha & N of Items \\
\hline .962 & 120 \\
\hline
\end{tabular}

The researcher calculated the construct validity of the test items using factor analysis. Each item of the tests was considered as a factor and the test results were used to see if there is adequate correlation between the scores. SPSS extracted the factors for the subjects. Factor analysis results for Nelson homogeneity test items wre between 0.76 and 0.92 ; indicating that the factors considered in the analysis showed enough correlation and that the tests validity hypothesis was supported.

\subsection{Statistics and Data Analysis}

In the next phase of the study, the participants were given Nelson vocabulary Test as the pretest. It should be mentioned that the scores and their distribution in different groups enjoyed normal distribution. As displayed in Table 2, the ratios of skewness and kurtosis over their respective standard errors were within the ranges of $+/$ 1.96.

Table 4. Normal distribution of the pretest scores in groups

\begin{tabular}{|c|c|c|c|c|}
\hline & & Male & Female & Control \\
\hline $\mathrm{N}$ & Valid & 24 & 24 & 23 \\
\hline Mean & & 25.9167 & 25.6250 & 25.6087 \\
\hline Skewness & & .079 & .235 & .377 \\
\hline Std. Error of Skewness & & .472 & .472 & .481 \\
\hline Kurtosis & & .519 & .230 & .787 \\
\hline Std. Error of Kurtosis & & .918 & .918 & .935 \\
\hline
\end{tabular}

The reliability of the pretest scores was calculated using Crombach alpha formula. As displayed in table 5. The results of Crombach alpha $(\alpha=.922)$ prove that the scores were reliable.

Table 5. Reliability of the pretest scores

\begin{tabular}{ll}
\hline Cronbach's Alpha & N of Items \\
\hline .922 & 75 \\
\hline
\end{tabular}

The researcher calculated the construct validity of the test items using factor analysis. Each item of the tests was considered as a factor and the test results were used to see if there is adequate correlation between the scores. SPSS extracted the factors for the subjects. Factor analysis results for pretest items were between 0.74 and 0.89 ; indicating that the factors considered in the analysis showed enough correlation and that the test scores were valid.

\section{Research Question 1}

Q1: Does oral summary of short stories have any effect on vocabulary learning of Iranian EFL learners at intermediate level?

An independent t-test was run to compare the experimental groups (Considered as one group) and control groups' mean score prior to the main study. Based on the results displayed in Table 5, it can be claimed that the 
experimental group $(\mathrm{M}=25.617, \mathrm{SD}=2.81)$ had a slightly higher mean than the control group $(\mathrm{M}=25.608, \mathrm{SD}$ $=2.75)$.

Table 6. Descriptive statistics

\begin{tabular}{llllll}
\hline & VAR00002 & $\mathrm{N}$ & Mean & Std. Deviation & Std. Error Mean \\
\hline General & 1.00 & 47 & 25.6170 & 2.81729 & .41094 \\
& 2.00 & 23 & 25.6087 & 2.75910 & .57531 \\
\hline
\end{tabular}

The results of the independent t-test $(\mathrm{t}(68)=0.12, \mathrm{p}=.991, \mathrm{r}=.712$ representing a weak effect size) (Table 7) indicate that the difference between the mean scores of the control group and experimental group is not meaningful.

Table 7. Independent samples test

\begin{tabular}{|c|c|c|c|c|c|c|c|c|c|c|}
\hline & & \multicolumn{2}{|c|}{$\begin{array}{l}\text { Levene's Test for } \\
\text { Equality of Variances }\end{array}$} & \multicolumn{7}{|c|}{ t-test for Equality of Means } \\
\hline & & \multirow[t]{2}{*}{$\mathrm{F}$} & \multirow[t]{2}{*}{ Sig. } & \multirow[t]{2}{*}{$\mathrm{t}$} & \multirow[t]{2}{*}{$\mathrm{df}$} & \multirow[t]{2}{*}{$\begin{array}{l}\text { Sig. } \\
\text { (2-tailed) }\end{array}$} & \multirow[t]{2}{*}{ Mean } & \multirow[t]{2}{*}{$\begin{array}{l}\text { Std. } \\
\text { Error }\end{array}$} & \multicolumn{2}{|c|}{$\begin{array}{l}\text { 95\% Confidence } \\
\text { Interval of the } \\
\text { Difference }\end{array}$} \\
\hline & & & & & & & & & Lower & Upper \\
\hline \multirow[t]{2}{*}{ General } & $\begin{array}{l}\text { Equal variances } \\
\text { assumed }\end{array}$ & \multirow{2}{*}{.036} & \multirow{2}{*}{.850} & .012 & 68 & .991 & .00833 & .71216 & -1.41276 & 1.42941 \\
\hline & $\begin{array}{l}\text { Equal variances not } \\
\text { assumed }\end{array}$ & & & .012 & 44.621 & .991 & .00833 & .70701 & -1.41599 & 1.43264 \\
\hline
\end{tabular}

It should be noted that the assumption of homogeneity of variances was met (Levene's $F=0.36, p=.850)$. That is why the first row of Table 7, i.e., "Equal variances assumed" was reported.

Next, the scores gained from the control group and both female and male participants (considered as one group) were compared on the posttest using independent samples t-test to find out if the difference is significant.

An independent t-test was run to compare the experimental group (considered as one group) and control groups' mean score on the posttest. Based on the results displayed in Table 8, it can be claimed that the experimental group $(\mathrm{M}=29.68, \mathrm{SD}=2.71)$ had a higher mean than the control group $(\mathrm{M}=27, \mathrm{SD}=2.67)$.

Table 8. Descriptive statistics

\begin{tabular}{llllll}
\hline & VAR00003 & $\mathrm{N}$ & Mean & Std. Deviation & Std. Error Mean \\
\hline general_posttest & 1.00 & 47 & 29.6809 & 2.71955 & .39669 \\
& 2.00 & 23 & 27.0000 & 2.67989 & .55880 \\
\hline
\end{tabular}

The results of the independent $t$-test $(\mathrm{t}(68)=3.89, \mathrm{p}=.00, \mathrm{r}=.688$ representing a large effect size) (Table 9) indicate that the difference between the mean scores of the control group and experimental group is meaningful. Thus, the first null hypothesis was rejected.

Table 9. Independent samples test

\begin{tabular}{|c|c|c|c|c|c|c|c|c|c|c|}
\hline & & \multicolumn{2}{|c|}{$\begin{array}{l}\text { Levene's Test for } \\
\text { Equality of Variances }\end{array}$} & \multicolumn{7}{|c|}{ t-test for Equality of Means } \\
\hline & & \multirow[t]{2}{*}{$\mathrm{F}$} & \multirow[t]{2}{*}{ Sig. } & \multirow[t]{2}{*}{$\mathrm{t}$} & \multirow[t]{2}{*}{$\mathrm{df}$} & \multirow[t]{2}{*}{$\begin{array}{l}\text { Sig. } \\
\text { (2-tailed) }\end{array}$} & \multirow[t]{2}{*}{ Mean } & \multirow[t]{2}{*}{$\begin{array}{l}\text { Std. } \\
\text { Error }\end{array}$} & \multicolumn{2}{|c|}{$\begin{array}{l}95 \% \text { Confidence } \\
\text { Interval of the } \\
\text { Difference }\end{array}$} \\
\hline & & & & & & & & & Lower & Upper \\
\hline \multirow[t]{2}{*}{ Posttest } & $\begin{array}{l}\text { Equal variances } \\
\text { assumed }\end{array}$ & \multirow{2}{*}{.041} & \multirow{2}{*}{.841} & 3.892 & 68 & .000 & 2.68085 & .68879 & 1.30638 & 4.05532 \\
\hline & $\begin{array}{l}\text { Equal variances not } \\
\text { assumed }\end{array}$ & & & 3.912 & 44.37 & .000 & 2.68085 & .68528 & 1.30008 & 4.06162 \\
\hline
\end{tabular}


It should be noted that the assumption of homogeneity of variances was met (Levene's $F=0.41, \mathrm{p}=.841)$. That is why the first row of Table 9, i.e., "Equal variances assumed" was reported.

\section{Research question 2}

Q2: if the answer to the research question 1 is "yes", which one of the male or female intermediate EFL learners benefits more?

In order to probe the answer to research Question 2, independent samples t-test was run to make sure the difference between the female participants and male participants on the pretest is not meaningful. As can be seen in Table 10 , the female group $(\mathrm{M}=25.91, \mathrm{SD}=2.84)$ had a slightly higher mean than the male group $(\mathrm{M}=25.62$, $\mathrm{SD}=2.93)$.

Table 10. Descriptive statistics

\begin{tabular}{llllll}
\hline & VAR00004 & $\mathrm{N}$ & Mean & Std. Deviation & Std. Error Mean \\
\hline Male_female_pretest & 1.00 & 24 & 25.9167 & 2.84248 & .58022 \\
& 2.00 & 24 & 25.6250 & 2.93128 & .59834 \\
\hline
\end{tabular}

The results of the independent $\mathrm{t}$-test $(\mathrm{t}(46)=.350, \mathrm{p}=.728, \mathrm{r}=.833$ representing a weak effect size) (Table 11) indicate that the difference between the mean scores of the control group and experimental group is not meaningful.

Table 11. Independent samples test

\begin{tabular}{|c|c|c|c|c|c|c|c|c|c|c|}
\hline & & \multicolumn{2}{|c|}{$\begin{array}{l}\text { Levene's Test for } \\
\text { Equality of } \\
\text { Variances } \\
\end{array}$} & \multicolumn{7}{|c|}{ t-test for Equality of Means } \\
\hline & & \multirow[t]{2}{*}{$\mathrm{F}$} & \multirow[t]{2}{*}{ Sig. } & \multirow[t]{2}{*}{$\mathrm{t}$} & \multirow[t]{2}{*}{ df } & \multirow[t]{2}{*}{$\begin{array}{l}\text { Sig. } \\
\text { (2-tailed) }\end{array}$} & \multirow[t]{2}{*}{ Mean } & \multirow[t]{2}{*}{$\begin{array}{l}\text { Std. } \\
\text { Error }\end{array}$} & \multicolumn{2}{|c|}{$\begin{array}{l}95 \% \text { Confidence } \\
\text { Interval of the } \\
\text { Difference }\end{array}$} \\
\hline & & & & & & & & & Lower & Upper \\
\hline \multirow[t]{2}{*}{ Male_female_pretest } & $\begin{array}{l}\text { Equal variances } \\
\text { assumed }\end{array}$ & \multirow{2}{*}{.207} & \multirow{2}{*}{.651} & .350 & 46 & .728 & .2916 & .8334 & -1.38602 & 1.96935 \\
\hline & $\begin{array}{l}\text { Equal variances } \\
\text { not assumed }\end{array}$ & & & .350 & 45.957 & .728 & .2916 & .8334 & -1.38606 & 1.96940 \\
\hline
\end{tabular}

Table 12. Descriptive statistics

\begin{tabular}{llllll}
\hline & VAR00005 & $\mathrm{N}$ & Mean & Std. Deviation & Std. Error Mean \\
\hline male_female_posttest & 1.00 & 24 & 29.8750 & 2.78681 & .56886 \\
& 2.00 & 24 & 29.7500 & 2.95252 & .60268 \\
\hline
\end{tabular}

An independent sample t-test was run to find out if the difference between the female group's and male group's is significant. As displayed in Table $13(\mathrm{t}(46)=.151, \mathrm{p}=.881, \mathrm{r}=.828)$ indicating that there is a weak effect size and that the difference between the groups is not meaningful. Thus, the second null hypothesis was supported.

Table 13. Independent samples test

\begin{tabular}{|c|c|c|c|c|c|c|c|c|c|c|}
\hline & & \multicolumn{2}{|c|}{$\begin{array}{l}\text { Levene's Test for } \\
\text { Equality of } \\
\text { Variances }\end{array}$} & \multicolumn{7}{|c|}{ t-test for Equality of Means } \\
\hline & & \multirow[t]{2}{*}{$\mathrm{F}$} & \multirow[t]{2}{*}{ Sig. } & \multirow[t]{2}{*}{$\mathrm{t}$} & \multirow[t]{2}{*}{ df } & \multirow[t]{2}{*}{$\begin{array}{l}\text { Sig. } \\
\text { (2-tailed) }\end{array}$} & \multirow[t]{2}{*}{ Mean } & \multirow[t]{2}{*}{$\begin{array}{l}\text { Std. } \\
\text { Error }\end{array}$} & \multicolumn{2}{|c|}{$\begin{array}{l}95 \% \text { Confidence } \\
\text { Interval of the } \\
\text { Difference }\end{array}$} \\
\hline & & & & & & & & & Lower & Upper \\
\hline \multirow[t]{2}{*}{ male_female_posttest } & $\begin{array}{l}\text { Equal variances } \\
\text { assumed }\end{array}$ & \multirow{2}{*}{.164} & \multirow{2}{*}{.688} & .151 & 46 & .881 & .12500 & .8287 & -1.5431 & 1.79318 \\
\hline & $\begin{array}{l}\text { Equal variances } \\
\text { not assumed }\end{array}$ & & & .151 & 45.847 & .881 & .12500 & .8287 & -1.5433 & 1.79333 \\
\hline
\end{tabular}


It should be mentioned that the assumption of homogeneity of variance was met (Leven's $\mathrm{F}=.164, \mathrm{P}=.688$ ).

\section{Discussion}

The study aimed at finding answers to the following research questions.

Q1: Does oral summary of short stories have any effect on vocabulary learning of Iranian EFL learners at intermediate level?

Q2: if the answer to the research question 1 is "yes", which one of the male or female intermediate EFL learners benefits more?

The findings of this study proved that oral summary of short stories can have a positive effect on learning vocabulary by Iranian intermediate EFL learners. This study also proved that the effect of oral production of short stories on learning vocabulary of Iranian EFL learners at intermediate level does not differ based on their gender.

The findings of this study are in line with the findings of Scott, Nagy, \& Flinspach (2008) who believe that meaning cannot be conveyed in isolation and that the socio-cultural context plays a considerable role in learning vocabulary either personal or academic. In fact, oral production of short stories is an act of placing words in a socio-cultural context which proved to increase vocabulary acquisition in this study.

As stated by Nunan (1999) learners should be given the maximum number of opportunities possible to practice the target language in meaningful context and situation. This study also proved that providing learners with a meaningful context (considering that short stories are meaningful context) can increase their vocabulary learning among language learners.

According to Taylor (1983), students acquire language by using it rather than learning it by studying it. Here by using oral summary of short stories students connect sentences and try to provide coherence, meaningful speech. Thus it can be claimed that the findings of this study are congruent with the Taylor (1983).

Considering that producing oral summary of short stories by language learners can have a positive effect on learning new vocabulary items and that no meaningful difference was observed between male and female subjects in the study, it can be concluded that language learners' production of oral summaries of short stories (as explained in the experimental groups) can be taken account as an effective classroom activity rather than production of oral summaries by classroom teachers (the control group). In addition, findings of this study can help promote lexical approach to language education in which learning new vocabulary is the target of language courses. This study had some limitations as the number of participants in this study. This investigation was limited to Iranian subjects with Persian and Azeri as their mother tongue and it's not clear if the nature of mother tongue would interfere with the research results. So, should care be taken not to over generalize the results of this research beyond its scope. This study like many other studies, suffers from a number of delimitations imposed by the researcher. The study is focused on oral summarization technique. The study is only concerned with the vocabulary ability of the subjects. The question whether oral summarization had an effect on other language skills, remained unanswered.

\section{References}

Abraham, R. (1981). The relationship of cognitive style to the use of grammatical rules by Spanish-speaking ESL students in editing written English. Academic Exchange Quarterly, 11(1), 93-97.

Al Dersi, Z. E. M. (2013). The use of short-stories for developing vocabulary of EFL learners. International Journal of English Language and Translation Studies, 1(1).

Alam, Y. S. (2007). A software system for second-language vocabulary learning. IEEE International Conference on Advanced Learning Technologies (pp. 130-132). http://dx.doi.org/10.1109/icalt.2007.37

Bengeleil, N., \& Paribakht, T. S. (2004). L2 reading proficiency and lexical inferencing by university EFL learners. Canadian Modern Language Review, 61, 225-249. http://dx.doi.org/10.3138/cmlr.61.2.225

Chastain, K. (1988). Developing second-language skills: Theory and practice (3rd ed.). San Diego: Harcourt Brace Jovanovich, Inc.

Craik, F. I. M., \& Lockhart, R. S. (1972). Levels of processing: A framework for memory research. J. Verbal Lang. Verbal Behav, 11, 671-684. http://dx.doi.org/10.1016/S0022-5371(72)80001-X

Daemi, M., \& Farnia, M. A. (2013). The effect of the storytelling on social skills of female preschools' students of educational district in Tabriz. Journal of Basic and Applied Scientific Research, 3(1), 197-203. 
Ellis, N. C. (1995). Vocabulary acquisition: Psychological perspectives and pedagogical implications. The Language Teacher, 19(2), 12-16.

Fehr, C. N., Davison, M. L., Graves, M. F., Sales, G. C., Seipel, B., \& Sekhran-Sharma, S. (2012). The effects of individualized, online vocabulary instruction on picture vocabulary scores: An efficacy study. The Journal of Asia TEFL, 25, 87-102. http://dx.doi.org/10.1080/09588221.2011.586640

Folse, K. S. (2006). The effect of type of written exercise on L2 vocabulary retention. Tesol Quarterly A Journal for Teachers of English to Speakers of Other Languages \& of Standard English As A Second Dialect, 40(2), 273-293. http://dx.doi.org/10.2307/40264523

Hsu, C., Hwang, G., \& Chang, C. (2013). A personalized recommendation-based mobile learning approach to improving the reading performance of EFL students. Computers \& Education, 63, 327-336. http://dx.doi.org/10.1016/j.compedu.2012.12.004

Isbell, R., Sobol, J., Lindauer, L., \& Lowrance, A. (2004). The effect of storytelling and story reading on the oral language complexity and story comprehension of young children. Early Childhood Educational Journal, 32(3). http://dx.doi.org/10.1023/B:ECEJ.0000048967.94189.a3

Lee, J., \& Choi, S. (2010). The effects of using multimedia title on preschool children's English listening skills, vocabulary, story recall ability and affective domains. Multimedia-Assisted Language Learning, 13(3), 237-252.

Lee, K. (2008). Are you memorizing words alphabetically? English Language Teaching, 20(3), 75-95. http://dx.doi.org/10.17936/pkelt.2008.20.3.004

Lee, K., Kim, S., Kim, S., \& Lee, Y. (2011).English language learning strategy instruction in Korean English textbooks for middle school students' self-regulated learning. Modern English Education, 12(1), 177-201.

Levy, M. (2009). Technologies in use for second language learning. The Modern Language Journal, 93, 769-782. http://dx.doi.org/10.1111/j.1540-4781.2009.00972.x

Li, J. (2010). Learning vocabulary via computer-assisted scaffolding for text processing. Computer Assisted Language Learning, 23, 253-375. http://dx.doi.org/10.1080/09588221.2010.483678

Looi, C., Wong, L., So, H., Seow, P., Toh, Y., Chen, W., ... Soloway, E. (2009). Anatomy of a mobilized lesson: $\begin{array}{lllll}\text { Learning my way. Computers \& } & \text { Education, }\end{array}$ http://dx.doi.org/10.1016/j.compedu.2009.05.021

Moghadam, S. H., Zainal, Z., \& Ghaderpour, M. (2012). A review on the important role of vocabulary knowledge in reading comprehension performance. Social and Behavioral Sciences, 66, 555-563. http://dx.doi.org/10.1016/j.sbspro.2012.11.300

Murdoch, G. (2002). Exploiting well-known short stories for language skills development. LATEFL LCS SIG Newsletter, 23, 9-17.

Nemati, A., \& Bayer M. J. (2008).Vocabulary retention technique through an organized learning scheme. Indian Linguistics, 69(1-4), 289-296.

Nunan, D. (1999). Second language teaching and learning. Boston: Heinle and Heinle Publishers.

Tavanpour, S., \& Gorjian, B. (2014). The effect of oral and written summary of short stories on learning translation markers among EFL learners: The case of writing descriptive essays. IJLLALW, 7(2), 354-366

Taylor, B. P. (1983). Teaching ESL: Incorporating a communicative, student-centered component. TESOL Quarterly, 17, 70-71. http://dx.doi.org/10.2307/3586425

Yip, F. W., \& Kwan, A. C. (2006). Online vocabulary games as a tool for teaching and learning English $\begin{array}{llll}\text { vocabulary. } & \text { Educational } & \text { Media } & \text { International, }\end{array}$ http://dx.doi.org/10.1080/09523980600641445

Yoshii, M. (2006). L1 and L2 glosses: Their effects on incidental vocabulary learning. Language Learning \& Technology, 10(3), 85-101.

Yun, J. (2011). The effects of hypertext glosses on L2 vocabulary acquisition: A meta-analysis. Computer Assisted Language Learning, 24, 39-58. http://dx.doi.org/10.1080/09588221.2010.523285 


\section{Copyrights}

Copyright for this article is retained by the author(s), with first publication rights granted to the journal.

This is an open-access article distributed under the terms and conditions of the Creative Commons Attribution license (http://creativecommons.org/licenses/by/4.0/). 